\title{
Orofacial changes of patients with congenital Zika syndrome in Northeast Brazil: an integrative literature review
}

\author{
- Marina Rosa Barbosa Faculdade de Odontologia do Recife (FOR), Fundação Odontológica Presidente Castello \\ Branco (FOPCB), Recife, PE, Brazil • Sérgio Bartolomeu de Farias Martorelli Faculdade de Odontologia do \\ Recife (FOR), Fundação Odontológica Presidente Castello Branco (FOPCB), Recife, PE, Brazil • Demostenes \\ Alves Diniz Hospital da Restauração Governador Paulo Guerra (HR), Universidade de Pernambuco (UPE), Recife, \\ PE, Brazil • Jéssica da Silva Cunha Hospital da Restauração Governador Paulo Guerra (HR), Universidade \\ de Pernambuco (UPE), Recife, PE, Brazil - Fernando de Oliveira Martorelli Centro Universitário Mauricio de \\ Nassau (UNINASSAU), Recife, PE, Brazil • Laís Azevedo Lins de Holanda Centro de Oncologia (CEON), Hospital \\ Universitário Oswaldo Cruz (HUOC), Universidade de Pernambuco (UPE), Recife, PE, Brazil
}

ABSTRACT | In 2015, in Northeast Brazil, cases of microcephaly associated with the outbreak of zika virus in South America were identified. This virus is transmitted by the biological vector Aedes aegypti, which also transmits dengue, yellow fever, and chikungunya viruses. The congenital Zika syndrome affected newborns with head circumference smaller than $32 \mathrm{~cm}$, compromising their central nervous system. Besides ocular lesions, hyperexcitability, and hypertonia, newborns also showed intracranial calcifications in imaging exams. If children with congenital Zika syndrome suffer maxillofacial alterations during embryonic development, they could have delayed tooth eruption and malformations. This study aims to perform an integrative review of the current literature about the health conditions of children with congenital Zika virus infection and the possible alterations of their oral cavity. This integrative literature review was performed by searching scientific articles in the PubMed, SciELO, and MEDLINE electronic databases with the descriptors "Zika Virus Infection", "Zika Virus", and "Microcephaly", which deal with clinical case reports and were indexed between 2016 and 2021. About 26 articles published entirely in English were analyzed after meeting the eligibility criteria. The studies contributed to better treatment conducts by showing the neurological, functional, and oral alterations in children with congenital Zika syndrome, including periodontal diseases, malocclusions, dental caries, bruxism, micrognathia, ankyloglossia, short labial frenum, dental trauma, and dysphagia.

DESCRIPTORS | Congenital Zika Syndrome; ZIKV Infection; Zika Virus.

RESUMO| Alterações orofaciais dos pacientes portadores de síndrome congênita de Zika no nordeste brasileiro: uma revisão integrativa da literatura • No nordeste brasileiro, no ano de 2015, foram identificados casos de microcefalia associados ao surto de Zika vírus no continente sul-americano, transmitido pelo vetor biológico Aedes Aegypti, também transmissor dos vírus da dengue, febre amarela, Chikungunya. A síndrome congênita de Zika manifestou-se em recém-nascidos com perímetro cefálico menor de $32 \mathrm{~cm}$, comprometendo o sistema nervoso central, apresentando em exames de imagem calcificações cerebrais, além de lesões oculares, hiperexcitabilidade e hipertonia. As crianças portadoras de síndrome congênita de Zika apresentam possíveis alterações maxilofaciais durante o desenvolvimento embrionário, ocasionando atraso na cronologia de erupção dentária e possíveis malformações. Este estudo busca realizar uma revisão integrativa da literatura atual sobre as condições de saúde e possíveis alterações na cavidade oral das crianças portadoras de infecção congênita por Zika vírus. A revisão integrativa da literatura foi realizada por meio de uma busca de artigos científicos na base de dados eletrônica PubMed, SciELO e MEDLINE, utilizando os descritores "Zika Virus Infection", "Zika Virus" e "Microcephaly", indexados no período de 2016 a 2021, que tratavam de relato de caso clínico. Após os critérios de elegibilidade, foram analisados integralmente 26 artigos publicados em língua inglesa. Os estudos mostraram as principais alterações bucais presentes nas crianças portadoras da síndrome congênita de Zika, como doenças periodontais, maloclusões, cárie dentária, bruxismo, micrognatia, anquiloglossia, encurtamento do freio labial, traumatismos dentários e disfagia, assim como as neurológicas e funcionais dos indivíduos, contribuindo para melhores condutas de tratamento.

DESCRITORES | Síndrome Congênita de Zika; Infecção por ZIKV; Vírus Zika.

CORRESPONDING AUTHOR | Sérgio Bartolomeu de Farias Martorelli Departamento de Ciências da Saúde, Patologia Oral e Cirurgia Buco-maxilo-facial, Faculdade de Odontologia do Recife (FOR), Fundação Odontológica Presidente Castelo Branco (FOPCB) • Rua Artur Coutinho, 143 Recife, PE, Brasil • 500100-280 E-mail: smartorelli_ maxilofacial@hotmail.com

- Received 04 23, 2021 • Accepted 11 26, 2021

- Dol http://dx.doi.org/10.11606/issn.2357-8041.clrd.2019.184736 


\section{INTRODUCTION}

According to the World Health Organization (WHO), microcephaly is a congenital anomaly in which a newborn's cephalic perimeter is shorter than $32 \mathrm{~cm}$ even after 39 weeks of gestational age. Since it can be transmitted prenatally (congenital), perinatally, and postnatally (acquired), gestational monitoring is essential. ${ }^{1}$

Zika is a single-stranded RNA virus with African and Asian strains. This neurotropic flavivirus transmitted by Aedes aegypti was first identified in 1947 in forests of Entebbe, Uganda, in a blood sample of a rhesus macaque. ${ }^{2}$ Because of the virus's wide geographic distribution, pandemics rapidly emerged Zika is expected to continue spreading by its transmitting agent. ${ }^{1-3}$. The first human cases were found in 1952-1954 in Nigeria and Tanzania. A Zika virus epidemic became a risk from 2005. The virus caused great damage to the French Polynesia in 2012, reaching Europe in 2013 and Brazil on April 29th, 2015.

The Zika virus disease is asymptomatic. Similarly to dengue, it is usually a mild febrile illness which causes cutaneous rash, arthralgia, or non-purulent conjunctivitis. Symptoms usually last up to a week. ${ }^{3}$ This disease currently has no specific treatment or vaccine, but possible randomized clinical trials on vaccine production are being conducted. Laboratory diagnosis mainly detects viral RNA genome by reverse transcriptase-polymerase chain reaction (RT-PCR) or virus isolation and specific IgM or IgG antibodies by serological tests. ${ }^{4}$

Six months after the Zika virus outbreak began, an unusual number of babies were born with microcephaly. ${ }^{5}$ They were mainly infected by the virus by maternal-fetal transmission by the amniotic fluid. The virus was found in two women pregnant with babies with microcephaly in the state of Paraíba, Brazil, and in tissue samples from a stillborn baby. ${ }^{4}$ The Brazilian and the French Polynesia Ministry of Health associated congenital malformation with Zika
V infection. Both countries also agreed that pregnant women were infected during the first and second trimesters of gestation. ${ }^{5}$

Brazil's Live Birth Information System (Sistema de Informações Sobre Nascidos Vivos - SINASC) notified 141 suspected cases of microcephaly in 2015 in in the states of Pernambuco, Paraíba, and Rio Grande do Norte, in northern Brazil. The Brazilian Ministry of Health declared this a public emergency. ${ }^{6}$ The Evandro Chagas Institute of the Ministry of Health isolated the Zika virus from the brain of a stillborn child by detecting it in cerebrospinal fluid (CSF), brain, and viscera fragments. ${ }^{7}$ As a result, IgM antibodies to the Zika virus were detected in the CSF of 12 children with microcephaly. The Ministry of Health's prevention policies aimed to create a vaccine to control congenital Zika. ${ }^{8}$

Studies from the Altino Ventura Foundation showed brain calcifications in CT scans and myopia, macular atrophy, and optic nerve hypoplasia in eye exams. ${ }^{9}$

The most prevalent alterations caused by microcephaly are intellectual disability, cerebral palsy, epilepsy, dysphagia, and behavioral disorders such as excessive crying, global hypertonia, seizures, epileptic seizures, and epileptic spasms..$^{10}$ Patients with microcephaly are most likely to develop oral diseases even if the virus did not affect their oral cavity during pregnancy. Oral hygiene is the best method of prevention and care against these oral diseases, which can directly and negatively impact the lives of these patients. ${ }^{11}$

Microcephaly is a genetic alteration that occurs during the neuronal proliferation phase, between the 3 rd and 4 th month of gestation. From the 3 rd to the $5^{\text {th }}$ month, imaging exams show malformations in fetal cortical development, neuronal migration disorders, and diffuse calcifications that cause neuronal death. ${ }^{12}$ Zika virus's pathogenesis greatly affects the central nervous system, increasing susceptibility to postnatal cortical development. ${ }^{13}$ 
The WHO classifies microcephaly by the following standards: Microcephaly, in which the newborn's (NB) head circumference is 2 standard deviations below the mean for gestational age and gender; and Severe Microcephaly, in which the NB's head circumference is 3 standard deviations below the mean. ${ }^{14}$

Over the past few decades, microcephaly incidence ranged from 1:6,250 cases to 1:8,500 cases, affecting mostly male children. In 2015, however, Brazil reached an excess number of cases without sex or skin color differences, and pregnant women of poorer socioeconomic conditions were the most affected..$^{15}$ These cases are monitored by SINASC by Code Q.02.

Patients with microcephaly have a small head circumference and could also present hearing loss, poor motor coordination, myopia, macular atrophy, optic nerve hypoplasia, hyperactivity, seizures, epilepsy, autism, cerebral palsy, ADHD, muscle rigidity, dysphagia, among others. ${ }^{16}$

Clinical diagnosis is made by measuring the head circumference using a flexible, non-elastic tape measure. The fetal head is measured at its greatest circumference, above the superciliary arches and the ears, and prominent at the posterior skull base. Laboratory diagnosis is done by collecting serum/ plasma from the newborn's CSF to confirm infection by Zika virus. ${ }^{17}$ Molecular biological tests and serological testing can also be conducted using RTPCR with serum, amniotic fluid, cerebrospinal fluid (CSF), saliva, and urine. Immunohistochemistry tests and serological testing such as ELISA IgM and IgG or PRNT detect Zika in the newborn's umbilical cord. Neuronal migration disorders, calcifications, ventricular dilatations, and loss of brain tissue can be visualized by computed tomography (CT) scans. Obstetric Ultrasonography is indicated for diagnosing structural abnormality of the central nervous system (CNS) and monitoring fetal and cerebral growth. Transfontanellar ultrasonography is used for more detailed examinations. ${ }^{18}$

The Brazilian Ministry of Health proposed to create a preventive vaccine against the Zika virus. Other countries, including the USA, are also developing this vaccine. However, the treatment of patients with microcephaly requires a multidisciplinary team with physicians, psychologists, physical therapists, speech therapists, dentists, social workers, nutritionists, nurses, etc. This study focuses on dental care for patients with microcephaly. ${ }^{18}$

Guiding question: what are the orofacial changes associated with congenital Zika syndrome?

\section{METHODOLOGY}

\section{Search strategy}

This integrative literature review was conducted by searching scientific articles in the electronic databases PubMed, Medline, and Portal CAPES, using the descriptors "Zika Virus Infection", "Zika Virus", and "Microcephaly" combined with the associations and outcomes of interest, as described in Figure 1. 


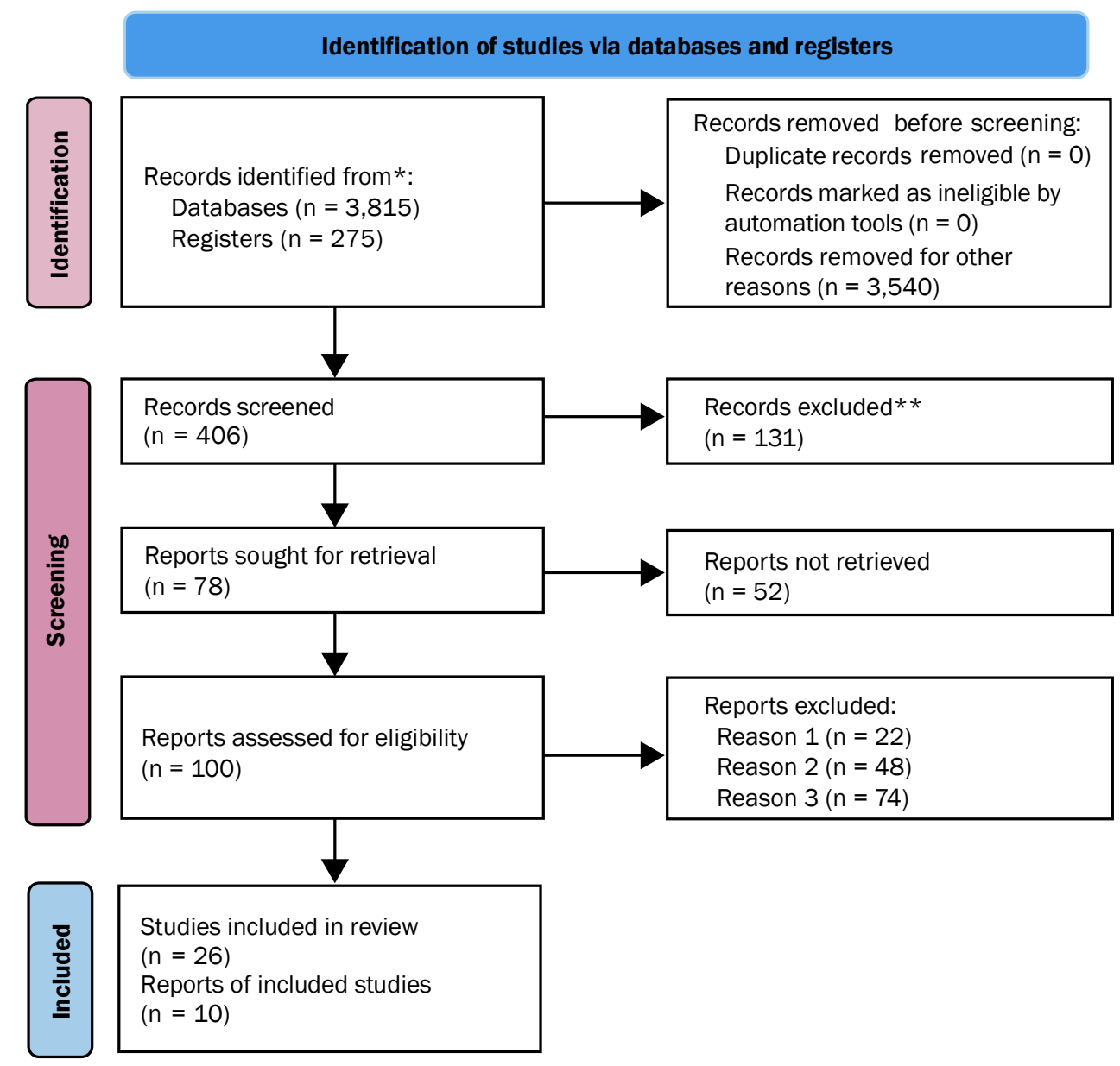

FIGURE 1 | Flowchart of the search strategy.

Source: PRISMA 2020 statement (Authors, 2021).

\section{Selection of articles}

The articles were assessed and selected by two separate researchers, who later compared their selected texts to reach consensus. If the researchers disagreed or doubted which articles to include in the study, they were joined by a third researcher. Articles that were indexed in both databases were considered only once. Then, selection had two phases: (1) reading the abstracts, and (2) qualitative analysis of the full texts.

\section{Eligibility criteria}

The inclusion criterion for article selection were: original articles available in full, published in English and Portuguese and indexed between 2016 and August 2020; articles regarding the oral health of patients with congenital Zika syndrome; clinical and laboratory mean studies that associate microcephaly with Zika virus; and studies regarding assistance and promotion of the oral health of patients with special needs. The following were not included: case-control studies, research with animal use, articles that relate microcephaly to other pathologies, articles that assess diagnoses of ZIKV, and etiological factors for congenital Zika syndrome in Northeast Brazil.

Our methodology followed the Preferred Reporting Items for Systematic Reviews and MetaAnalyses (PRISMA) recommendations. Articles that 
did not fit the inclusion criteria and repeated articles were excluded. After a full reading of the remaining articles was performed, our final sample included 26 articles.

Theses, dissertations, and monographs were not used, since they are impractical to search for and were not included in database.

\section{RESULTS AND DISCUSSION}

\section{Results}

This study aimed to analyze the literature on congenital Zika syndrome. We observed the clinical and pathological characteristics and diagnostic methods of the disease, assessing the patient as a whole and following the principles of the Brazilian Unified Health System (Sistema Único de Saúde
- SUS): equity, universality, and social equality. Our integrative review found recent studies on how the virus originated and spread until the first cases of Zika virus infection appeared. We observed the virus's stages of development and pathological advances, diagnosis by clinical and laboratory tests, risk factors and lesions associated with congenital infection, and the use of scientific means to create a vaccine for both treatment and prevention of the disease, as shown in Table 1.

Twenty-six scientific articles were selected according to the criteria. Results showed that the oral cavity of patients with congenital Zika syndrome changed. Among these articles, 10 were selected for evaluation and description of data (Table 1): 1 Retrospective Study, 5 Cross-Sectional Studies, 2 Longitudinal Studies, 1 Scopus Review, and 1 Case Series.

TABLE 1 | Selection of articles according to the author, type of study, objectives, methodology, results, and conclusion.

\begin{tabular}{|c|c|c|c|c|}
\hline Author and Study & Objective & Methodology & Results & Conclusion \\
\hline $\begin{array}{c}\text { Leal et al., } 2017, \\
\text { retrospective } \\
\text { study }^{1}\end{array}$ & $\begin{array}{c}\text { To assess the } \\
\text { characteristics of } \\
\text { dysphagia in nine } \\
\text { children in Brazil with } \\
\text { microcephaly caused } \\
\text { by congenital Zika virus } \\
\text { infection. }\end{array}$ & $\begin{array}{l}\text { A descriptive, retrospective } \\
\text { study of a case series was } \\
\text { conducted by reviewing } \\
\text { the medical records of } \\
\text { nine children in Brazil with } \\
\text { dysphagia and microcephaly } \\
\text { caused by congenital Zika } \\
\text { syndrome (CZS) who were } \\
\text { diagnosed during the } 2015 \\
\text { microcephaly epidemic. }\end{array}$ & $\begin{array}{l}\text { All babies had some degree } \\
\text { of neurological damage, with } \\
\text { delays in development and limb } \\
\text { hypertonia. Most babies had } \\
\text { abnormal tongue movements, } \\
\text { which contributes to dysphagia. }\end{array}$ & $\begin{array}{l}\text { Affected children had } \\
\text { marked oral dysfunction and } \\
\text { dystonic tongue movements } \\
\text { and lacked pharyngeal } \\
\text { sensitivity, which increases } \\
\text { the risk of aspiration, } \\
\text { especially of liquid foods. }\end{array}$ \\
\hline $\begin{array}{l}\text { Fonteles et al., } \\
2018 \text {, cross- } \\
\text { sectional and } \\
\text { descriptive } \\
\text { study }^{10}\end{array}$ & $\begin{array}{l}\text { To assess the lingual } \\
\text { frenulum of children } \\
\text { with congenital Zika } \\
\text { syndrome (CZS). }\end{array}$ & $\begin{array}{l}\text { Data collection and orofacial } \\
\text { assessment of babies with } \\
\text { congenital Zika syndrome } \\
\text { (CZS). }\end{array}$ & $\begin{array}{c}\text { The lingual frenulum was visible } \\
\text { in } 34(63 \%) \text { infants, whereas } 20 \\
(37 \%) \text { infants required a specific } \\
\text { maneuver to retract the tongue for } \\
\text { visibility. }\end{array}$ & $\begin{array}{l}\text { Children with CZS had a } \\
\text { short lingual frenulum. }\end{array}$ \\
\hline $\begin{array}{l}\text { Cavalcanti } \\
\text { et al., } 2018, \\
\text { longitudinal } \\
\text { study }^{19}\end{array}$ & $\begin{array}{l}\text { To investigate the } \\
\text { occurrence of signs } \\
\text { and symptoms related } \\
\text { to primary tooth } \\
\text { eruption in children } \\
\text { with congenital Zika } \\
\text { syndrome. }\end{array}$ & $\begin{array}{l}79 \text { children were assessed } \\
\text { for } 24 \text { months. Their medical } \\
\text { records were analyzed. The } \\
\text { data were presented using } \\
\text { descriptive and inferential } \\
\text { statistics (chi-square test). }\end{array}$ & $\begin{array}{l}94.9 \% \text { of children showed two or } \\
\text { more signs and symptoms related } \\
\text { to tooth eruption simultaneously, } \\
\text { including increased salivation } \\
(91.1 \%), \text { irritability }(86.1 \%), \text { and } \\
\text { itchy gums }(83.5 \%) \text {. }\end{array}$ & $\begin{array}{l}\text { Children with congenital } \\
\text { Zika syndrome had } \\
\text { increased salivation, } \\
\text { irritability, and itchy gums, } \\
\text { all related to primary teeth } \\
\text { eruption. }\end{array}$ \\
\hline $\begin{array}{l}\text { Carvalho } \\
\text { et al., } 2019 \text {, } \\
\text { observational } \\
\text { cross-sectional } \\
\text { study }^{20}\end{array}$ & $\begin{array}{l}\text { To investigate possible } \\
\text { soft-tissue, bone, } \\
\text { and / or dental } \\
\text { malformations } \\
\text { in patients with } \\
\text { congenital Zika virus } \\
\text { syndrome. }\end{array}$ & $\begin{array}{l}30 \text { children born with ZIKV and } \\
30 \text { children born without ZIKV } \\
\text { (control group) were included in } \\
\text { the study and assessed for } 24 \\
\text { consecutive months. }\end{array}$ & $\begin{array}{l}\text { Babies with ZIKV showed a high } \\
\text { prevalence of inadequate resting } \\
\text { tongue posture, micrognathia, } \\
\text { changes in the shape and / or } \\
\text { number of teeth, alterations in the } \\
\text { sequence of tooth eruption and } \\
\text { muscle spasms, delayed eruption, } \\
\text { and narrow arched palate. }\end{array}$ & $\begin{array}{l}\text { Children with ZIKV were } \\
\text { more inclined to have } \\
\text { delayed primary tooth } \\
\text { eruption, inadequate tongue } \\
\text { posture, and short labial } \\
\text { and lingual frenulum. }\end{array}$ \\
\hline
\end{tabular}


TABLE 1 | Continuation

\begin{tabular}{|c|c|c|c|c|}
\hline Author and Study & Objective & Methodology & Results & Conclusion \\
\hline $\begin{array}{l}\text { Silva, 2020, } \\
\text { longitudinal } \\
\text { study }^{21}\end{array}$ & $\begin{array}{l}\text { To assess the presence } \\
\text { of dental anomalies in } \\
13 \text { babies diagnosed } \\
\text { with congenital ZIKV } \\
\text { syndrome. }\end{array}$ & $\begin{array}{l}\text { The first } 29 \text { reported cases } \\
\text { of children with microcephaly } \\
\text { admitted to special maternal } \\
\text { and childcare units between } \\
\text { July and October } 2015 \text { were } \\
\text { assessed. Of these children, } \\
\text { three died and } 13 \text { lived in } \\
\text { other municipalities; thus, } \\
\text { only } 13 \text { patients remained for } \\
\text { assessment in Recife, PE. }\end{array}$ & $\begin{array}{l}\text { Dental radiographs showed } \\
\text { that, in the first half, all children } \\
\text { had dental germs; at the end of } \\
\text { the study, they had incomplete } \\
\text { primary dentition. }\end{array}$ & $\begin{array}{l}\text { Abnormal chronology of } \\
\text { tooth eruption and tooth } \\
\text { development disorders in } \\
\text { children with microcephaly } \\
\text { who were infected by ZIKV } \\
\text { indicate that viruses could } \\
\text { affect odontogenesis. }\end{array}$ \\
\hline $\begin{array}{l}\text { Ribeiro RA, } \\
2020 \text {, cross- } \\
\text { sectional and } \\
\text { observational } \\
\quad \text { study }^{22}\end{array}$ & $\begin{array}{l}\text { To assess the oral } \\
\text { and maxillofacial } \\
\text { characteristics } \\
\text { of children with } \\
\text { microcephaly } \\
\text { associated with } \\
\text { congenital Zika } \\
\text { syndrome. }\end{array}$ & $\begin{array}{c}\text { Assessment of } 61 \text { patients } \\
\text { with microcephaly / CZS born } \\
\text { between June } 2015 \text { and } \\
\text { September } 2017 \text { and of a } \\
\text { control group with } 58 \text { non-CZS } \\
\text { children born in the same } \\
\text { period. }\end{array}$ & $\begin{array}{c}\text { Narrow palate and late primary } \\
\text { tooth eruption were prevalent } \\
\text { in the group with microcephaly } \\
\text { caused by Zika. }\end{array}$ & $\begin{array}{l}\text { Children with microcephaly } \\
\text { caused by congenital Zika } \\
\text { infection showed functional, } \\
\text { oral, and maxillofacial } \\
\text { changes and smaller facial } \\
\text { development. }\end{array}$ \\
\hline $\begin{array}{l}\text { Oliveira, } 2020, \\
\text { cross-sectional } \\
\text { study }^{23}\end{array}$ & $\begin{array}{l}\text { To investigate oral } \\
\text { and maxillofacial } \\
\text { outcomes in children } \\
\text { with congenital Zika } \\
\text { syndrome. }\end{array}$ & $\begin{array}{c}\text { Assessment of } 45 \text { children with } \\
\text { CZS and of } 50 \text { healthy controls } \\
\text { in the state of Sergipe, Brazil, } \\
\text { from February } 2018 \text { to June } \\
2018 .\end{array}$ & $\begin{array}{c}\text { Patients with CZS were oral } \\
\text { breathing, had difficulty } \\
\text { swallowing, excessive salivation, } \\
\text { abnormal attachment of the upper } \\
\text { lip frenulum, high-arched palate, } \\
\text { dental enamel defects, and late } \\
\text { tooth eruption. }\end{array}$ & $\begin{array}{l}\text { Children with CZS had } \\
\text { more problems related to } \\
\text { breastfeeding, low weight, } \\
\text { and oral and maxillofacial } \\
\text { abnormalities. }\end{array}$ \\
\hline $\begin{array}{l}\text { D'Agostino } \\
\text { ÉS, 2020, } \\
\text { cross-sectional } \\
\text { study }^{24}\end{array}$ & $\begin{array}{l}\text { To describe the } \\
\text { chronology and } \\
\text { sequence of primary } \\
\text { teeth in children with } \\
\text { microcephaly caused } \\
\text { by fetal exposure to the } \\
\text { Zika virus. }\end{array}$ & $\begin{array}{l}\text { Assessment of } 74 \text { children from } \\
\text { a neuropediatric referral unit in } \\
\text { Salvador, Bahia, in } 2017 .\end{array}$ & $\begin{array}{l}\text { The average eruption time is } \\
17.92 \text { months for maxillary } \\
\text { teeth and } 11.57 \text { months for the } \\
\text { mandible teeth. The first teeth } \\
\text { erupted in the lower arch, and the } \\
\text { molars and / or canines erupted } \\
\text { before the incisors. }\end{array}$ & $\begin{array}{c}\text { The chronology and eruption } \\
\text { sequence of primary teeth } \\
\text { changed. }\end{array}$ \\
\hline $\begin{array}{l}\text { Silva Sobrinho, } \\
\text { 2021, scope } \\
\text { review }^{25}\end{array}$ & $\begin{array}{l}\text { To analyze published } \\
\text { scientific evidence } \\
\text { on the most common } \\
\text { orofacial disorders } \\
\text { in children with } \\
\text { microcephaly } \\
\text { associated with ZIKV } \\
\text { infection. }\end{array}$ & $\begin{array}{c}\text { PubMed, EMBASE, Scopus, } \\
\text { and Health Virtual Library } \\
\text { databases were used for } \\
\text { research. }\end{array}$ & $\begin{array}{l}11 \text { studies conducted in } \\
\text { Northeast Brazil between } 2018 \\
\text { and } 2020 \text { were selected. }\end{array}$ & $\begin{array}{l}\text { The chronology of tooth } \\
\text { eruption and teeth and oral } \\
\text { structures changed the } \\
\text { most. }\end{array}$ \\
\hline $\begin{array}{l}\text { Aragón et al., } \\
\text { 2021, case } \\
\text { series }^{11}\end{array}$ & $\begin{array}{l}\text { To describe the } \\
\text { dental, occlusal, } \\
\text { and craniofacial } \\
\text { characteristics of } \\
\text { three children with } \\
\text { congenital Zika virus } \\
\text { infection. }\end{array}$ & $\begin{array}{l}\text { Case report of three children } \\
\text { with congenital microcephaly } \\
\text { caused by Zika virus. }\end{array}$ & $\begin{array}{l}\text { The children had a short upper } \\
\text { third of the face, hypertonic } \\
\text { masticatory muscles and } \\
\text { hypotonic swallowing muscles, } \\
\text { dysphagia, dyslalia, bruxism, } \\
\text { labial incompetence, tongue } \\
\text { interposition, hypersalivation, } \\
\text { and epilepsy. The complete } \\
\text { primary teeth with normal dental } \\
\text { morphology were affected by } \\
\text { altered tooth eruption, dental } \\
\text { caries, and dental malocclusion. }\end{array}$ & $\begin{array}{l}\text { The children's dental } \\
\text { formula and dental } \\
\text { morphology of the } \\
\text { primary dentition did not } \\
\text { change. However, they } \\
\text { have severe chewing and } \\
\text { speech limitations, facial } \\
\text { disproportion, and occlusal } \\
\text { problems. }\end{array}$ \\
\hline
\end{tabular}

Source: Authors (2021). 


\section{Discussion}

In 2015, in Northeast Brazil, mainly in the state of Pernambuco, the number of children born with microcephaly increased significantly, indicating a possible association with Zika virus infection during pregnancy. About 29 babies with microcephaly were admitted in the main public hospitals of Pernambuco, which are the Pediatric Infectious Diseases Unit of the University Hospital Oswaldo Cruz, University of Pernambuco, and the Professor Fernando Figueira Institute of Integral Medicine. Thus, the Pernambuco Health Department notified an unusual incidence of microcephaly cases to the Brazilian Ministry of Health. ${ }^{21}$

We agree that ZIKV infection during pregnancy can cause severe defects and abnormalities in the neurological and craniofacial development of children. Babies infected with congenital Zika virus develop problems such as epilepsy, vision loss, and developmental delays as they grow. The new congenital Zika syndrome should be classified as a TORCH infection (toxoplasmosis, syphilis, varicellazoster, parvovirus B19, rubella, cytomegalovirus, and herpes), which are some of the most common infections associated with mother-to-child infections transmitted during pregnancy that cause congenital anomalies, including maxillofacial disorders. ${ }^{21}$

Ameloblasts that synthesize the enamel of the tooth crown are formed during embryonic teeth development. Once damaged, the enamel cannot recover. The formation of dental tissues, enamel, and dentin depends on coordinated cellular interactions between the oral epithelium and the ectomesenchyme, derived from the neural crest.

Dental radiographs obtained during the patients' first trimester of life aimed to verify the extent of ZIKV infection and its impact on the development of dental germs. The results revealed that children born with congenital Zika syndrome have dental germs. Radiolucency in the teeth pre and posteruption confirmed that the tooth tissue underwent calcification disorder during enamel formation. Panoramic radiographs also showed both qualitative and quantitative dental development anomalies, prevalent in children with neurological disorders. ${ }^{12,21}$

To answer the guiding question, children with congenital ZIKV infection have short labial and lingual frenulum, narrow palate, interfered tooth eruption, hypersalivation, muscle spasms, hyperplasia of the alveolar ridge, no cleft lip or palate, agenesis of upper and lower deciduous incisors, microdontia, micrognathia, supernumerary teeth, eruption cysts, dental hypoplasia, and diffuse opacity enamels. Infections during gestation are considered a risk factor for dental lesions and congenital anomalies in embryos.

\section{FINAL CONSIDERATIONS}

Finally, we conclude that the association of Zika virus with microcephaly cases in Brazil can be proved by scientific evidence. However, we observed that scientific and clinical studies should be more accessible to dental surgeons, whereas microcephaly patients need more retrospective, randomized clinical studies regarding treatment conduct and the use of medicines.

\section{REFERENCES}

1. Leal MC, van der Linden V, Bezerra TP, Valois L, Borges ACG, Antunes MMC, et al. Characteristics of dysphagia in infants with microcephaly caused by congenital Zika virus infection, Brazil, 2015. Emerg Infect Dis. 2017;23(8):1253-9. Doi: https://doi.org/10.3201/eid2308.170354

2. Haby MM, Pinart M, Elias V, Reveiz L. Prevalence of asymptomatic Zika virus infection: a systematic review. Bull World Health Organ. 2018;96(6):402-13D. Doi: https://doi. org/10.2471/BLT.17.201541

3. Subissi L, Dub T, Besnard M, Mariteragi-Helle T, Nhan T, Lutringer-Magnin D, et al. Zika virus infection during pregnancy and effects on early childhood development, French Polynesia, 2013-2016. Emerg Infect Dis. 2018;24(10):1850-8. Doi: https://doi.org/10.3201/eid2410.172079 
4. Shakib K. Epidemic of Zika virus and maxillofacial surgery. Br J Oral Maxillofac Surg. 2016;54(4):355-7. Doi: https://doi. org/10.1016/j.bjoms.2016.02.001

5. Castanha PMS, Souza WV, Braga C, Araujo TVB, Ximenes RAA, Albuquerque MFPM, et al. Perinatal analyzes of Zikaand dengue virus-specific neutralizing antibodies: a microcephaly case-control study in an area of high dengue endemicity in Brazil. PLoS Negl Trop Dis. 2019;13(3):eooo7246. Doi: https://doi.org/10.1371/journal.pntd.0oo7246

6. Panchaud A, Stojanov M, Ammerdorffer A, Vouga M, Baud D. Emerging role of Zika virus in adverse fetal and neonatal outcomes. Clin Microbiol Rev. 2016;29(3):659-94. Doi: https://doi.org/10.1128/CMR.0o014-16

7. Duron RM, Herrera-Páz EF, Salgado Rodríguez AM, Castro Carías CE, Fernández-Rodríguez D, Cabrera JS, et al. Cephalic circumference curves and potential anthropometric differences in Latin America and the world. Rev Ecuat Neurol. 2019;28(1):47-55.

8. Eickmann SH, Carvalho MDCG, Ramos RCF, Rocha MAW, van der Linden V, Silva PFS. Zika virus congenital syndrome. Cad Saude Publica. 2019;32(7):eooo47716. Doi: https://doi. org/10.1590/0102-311Xoo047716

9. Feitosa IML, Schuler-Faccini L, Sanseverino MTV. Important aspects of congenital Zika syndrome for the pediatrician and the neonatologist. Bol Cient Pediatr. 2016;5(3):75-80.

10. Fonteles CSR, Ribeiro EM, Santos MSA, Leite RFP, Assunção GS, Monteiro AJ, et al. Lingual frenulum phenotypes in Brazilian infants with congenital Zika syndrome. Cleft Palate Craniofac J. 2018;55(10):1391-8. Doi: https://doi. org/10.1177/1055665618766999

11. Aragón N, Díaz C, Contreras A. Dental, occlusal, and craniofacial features of children with microcephaly due to congenital Zika infection: 3 cases report from Valle del Cauca, Cali - Colombia - 2020. Cleft Palate Craniofac J. 2021;58(10):1318-25. Doi: https://doi.org/10.1177/1055665621990978

12. Carvalho IF, Alencar PNB, Andrade MDC, Silva PGB, Carvalho EDF, Araújo LS, et al. Clinical and x-ray oral evaluation in patients with congenital Zika virus. J Appl Oral Sci. 2019;27:e20180276. Doi: https://doi.org/10.1590/1678-77572018-0276

13. Nunes ML, Carlini CR, Marinowic D, Kalil Neto F, Fiori $\mathrm{HH}$, Scotta MC, et al. Microcephaly and Zika virus: a clinical and epidemiological analysis of the current outbreak in Brazil. J Pediatr (Rio J). 2016;92(3):230-40. Doi: https://doi. org/10.1016/j.jped.2016.02.009
14. Roma JHF, Alves RC, Silva VS, Ferreira MJ, Araújo C, Pavoni JHC. Descriptive study of suspected congenital Zika syndrome cases during the 2015-2016 epidemic in Brazil. Rev Soc Bras Med Trop. 2019;52:e20190105. Doi: https:// doi.org/10.1590/o037-8682-0105-2019

15. Trigueiro SA, Neves BF, Aguiar MSB, Araújo JSS. Correlation between cephalic circumference at birth and ocular alterations in patients with microcephaly potentially associated with Zika Virus infection. Rev Assoc Med Bras. 2019;65(6):909-13. Doi: https://doi.org/10.159o/18o69282.65.6.909

16. Ventura CV, Maia M, Ventura BV, van der Linden V, Araújo $\mathrm{EB}$, Ramos RC, et al. Ophthalmological findings in infants with microcephaly and presumable intra-uterus Zika virus infection. Arq Bras Oftalmol. 2016;79(1):1-3. Doi: https://doi. org/10.5935/0004-2749.20160002

17. Counotte MJ, Meili KW, Taghavi K, Calvet G, Sejvar J, Low $\mathrm{N}$. Zika virus infection as a cause of congenital brain abnormalities and Guillain-Barré syndrome: A living systematic review. F10ooRes. 2019;8:1433. Doi: https://doi.org/10.12688/ f10ooresearch.19918.1

18. Rice ME, Galang RR, Roth NM, Ellington SR, Moore CA, Valencia-Prado M, et al. Vital signs: Zika-associated birth defects and neurodevelopmental abnormalities possibly associated with congenital Zika virus infection - U.S. Territories and Freely Associated States, 2018. MMWR Morb Mortal Wkly Rep. 2018;67(31):858-67. Doi: https://doi.org/10.15585/ mmwr.mm6731e1

19. Cavalcanti AFC, Aguiar YPC, Oliveira Melo AS, Freitas Leal JIB, Cavalcanti AL, Cavalcanti SDLB. Teething symptoms in children with congenital Zika syndrome: a 2-year followup. Int J Paediatr Dent. 2019;29(1):74-8. Doi: https://doi. org/10.1111/ipd.12431

20. Carvalho IF, Alencar PNB, Carvalho de Andrade MD, Silva PGB, Carvalho EDF, Araújo LS, et al. Clinical and x-ray oral evaluation in patients with congenital Zika Virus. J Appl Oral Sci. 2019;27:e20180276. Doi: https://doi.org/10.1590/16787757-2018-0276

21. Silva MCPM, Arnaud MA, Lyra MCA, Alencar Filho AV, Rocha MAW, Ramos RCF, et al. Dental development in children born to Zikv-infected mothers: a case-based study. Arch Oral Biol. 2020;110:104598. Doi: https://doi.org/10.1016/j.archoralbio.2019.104598

22. Ribeiro RA, Mattos A, Meneghim MC, Vedovello SAS, Borges TMD, Santamaria M Jr. Oral and maxillofacial outcomes 
in children with microcephaly associated with the congenital Zika syndrome. Eur J Orthod. 2020;43(3):346-52. Doi: https://doi.org/10.1093/ejo/cjaao36

23. Oliveira AMM, Melo EGM, Mendes MLT, Santos Oliveira SJG, Tavares CSS, Vaez AC, et al. Oral and maxillofacial conditions, dietary aspects, and nutritional status of children with congenital Zika syndrome. Oral Surg Oral Med Oral Pathol Oral Radiol. 2020;130(1):71-7. Doi: https://doi.org/10.1016/j. 0ooo.2020.02.019
24. D’Agostino ES, Chagas JRLP, Cangussu MCT, Vianna MIP. Chronology and sequence of deciduous teeth eruption in children with microcephaly associated to the Zika virus. Spec Care Dentist. 2020;40(1):3-9. Doi: https://doi.org/10.1111/scd.12435 25. Silva Sobrinho AR, Ramos LFS, Maciel YL, Maurício HA, Cartaxo RO, Ferreira SJ, et al. Orofacial features in children with microcephaly associated with Zika virus: a scoping review. Oral Dis. 2021:1-7. Doi: https://doi.org/10.1111/ odi.13804 